\title{
Association between sarcopenic obesity, muscle strength and risk of cardiovascular and cardiometabolic diseases in the elderly: A systematic review
}

\author{
Associação entre obesidade sarcopênica, força \\ muscular e risco de doenças cardiovasculares \\ e cardiometabólicas em idosos: \\ uma revisão sistemática
}

\author{
Luiz Sinésio SILVA NETO' (iD) 0000-0002-3182-7727 \\ Alessandra MEDEIROS² (D) 0000-0002-7962-7185 \\ Andreia TRAVASSOS 3 iD 0000-0003-4067-4184 \\ Neila Barbosa OSÓRIO4 (D) 0000-0002-6346-0288

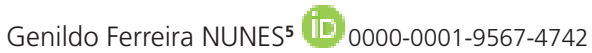

\section{A B S T R A C T}

To describe the findings in the literature about the association between sarcopenic obesity, muscle strength and risk factors and/or cardiometabolic or cardiovascular diseases in the elderly. A research was carried out

\footnotetext{
1 Universidade Federal do Tocantins, Curso de Medicina, Programa de Pós-Graduação em Ensino e Ciências e Saúde. Campus Universitário 109 Norte, Avenida NS 15 ALCNO 14, Bloco UMA/UFT. 77001-090, Palmas, TO, Brasil. Correspondence to: LS SILVA NETO. E-mail: <luizneto@uft.edu.br>.

2 Universidade Federal de São Paulo, Programa de Pós-Graduação Interdisciplinar em Ciências da Saúde, Departamento de Fisioterapia. Santos, SP, Brasil.

3 Instituto de Ensino e Pesquisa Objetivo, Curso de Fisioterapia, Departamento de Fisioterapia. Palmas, TO, Brasil.

${ }^{4}$ Universidade Federal do Tocantins, Programa de Pós-Graduação em Educação, Colegiado de Pedagogia. Palmas, TO, Brasil

5 Universidade Federal do Tocantins, Curso de Medicina, Grupo de Pesquisa em Envelhecimento Humano. Palmas, TO, Brasil.
}

\footnotetext{
How to cite this article

Silva Neto LS, Medeiros A, Travassos A, Osório NB, Nunes GF. Association between sarcopenic obesity, muscle strength and risk of cardiovascular and cardiometabolic diseases in the elderly: A systematic review. Rev Nutr. 2019;32:e180237. http://dx.doi.org/10.1590/1678-9865201932e180237
} 
in the following databases: Medical Literature Analysis and Retrievel System Online, Web of Science, Literatura Latino-Americana e do Caribe em Ciências da Saúde (Latin America and Caribbean Health Sciences Literature) and Capes Journals, using the following search terms in English, Spanish and Portuguese: "obesity sarcopenic" OR "sarcopenic obesity" in the title AND "cardiometabolic disease" OR "cardiovascular disease" OR "metabolic syndrome" OR "insulin resistance" in the title/abstract AND "aged" in all fields of search with the variation of the "muscle strength" descriptor in all fields of this research. Articles were selected according to the following exclusion criteria: studies evaluating only sarcopenia and the risk of cardiometabolic/cardiovascular disease in the elderly, studies evaluating only obesity and the risk of cardiometabolic/cardiovascular disease in the elderly, studies that did not present the used method, studies in animals and studies that were not in Portuguese, English or Spanish. The researchers of the present study found a heterogeneity of methods for the identification of sarcopenic obesity, and a transversal cohort was used in most of the studies. It was possible to verify the association of sarcopenic obesity with risk factors and/or cardiometabolic or cardiovascular disease. Sarcopenic obesity is associated with risk factors and/or cardiometabolic or cardiovascular disease in the elderly. Establishing a robust definition of sarcopenic obesity in the elderly is necessary for further clinical studies and interventions.

Keywords: Cardiovascular diseases. Elderly. Metabolic diseases. Obesity. Sarcopenia.

\section{RE S U M O}

Descrever os achados da literatura sobre a associação entre obesidade sarcopenia, força muscular e fatores de risco elou doenças cardiometabólicas ou doenças cardiovasculares em idosos. Foi realizada uma busca nas bases Medical Literature Analysis and Retrievel System Online, Web of Science, Literatura Latino-Americana e do Caribe em Ciências da Saúde, e Periódicos Capes, nos idiomas inglês, espanhol e português, com as seguintes chaves de busca: "obesity sarcopenic" OR "sarcopenic obesity" no título AND "cardiometabolic disease" OR "cardiovascular disease" OR "metabolic syndrome" OR "insulin resistance" no título/resumo AND "aged" em todos os campos e com a variação de utilização do descritor "muscle strenght" em todos os campos do trabalho. A seleção dos artigos seguiu os seguintes critérios de exclusão: trabalhos que avaliam apenas sarcopenia e risco de doenças cardiovasculares/doenças cardiometabólicas em idosos; trabalhos que avaliam apenas obesidade e risco de doenças cardiovasculares/doenças cardiometabólicas em idosos; trabalhos que apresentam avaliações sem apresentar o método utilizado; estudos realizados em animais e outros que não estejam em português, inglês ou espanhol. A estratégia de busca identificou 235 publicações nas bases de dados e, após a utilização dos critérios de inclusão e exclusão, foram inseridos 17 artigos para análise nessa revisão. Houve heterogeneidade de métodos na identificação da obesidade sarcopênica, tendo sido utilizado o corte transversal na maioria dos estudos. Foi possível verificar a associação de obesidade sarcopênica com os fatores de risco elou doenças cardiovasculares ou doenças cardiometabólicas em 16 estudos. A obesidade sarcopênica está associada a fatores de risco elou doenças cardiometabólicas ou doenças cardiovasculares em idosos. O estabelecimento de uma definição robusta de obesidade sarcopênica em idosos é necessário para estudos e intervenções clínicas.

Palavras-chave: Doenças cardiovasculares. Idosos. Doenças metabólicas. Obesidade. Sarcopenia.

\section{INTRODUCTION}

The aging process is characterized by biological changes, including changes in body composition. Changes such as Fat-Free Mass (FFM) reduction and Fat Mass (FM) increase are adjuvant in aging. Sarcopenia is a geriatric syndrome characterized by quantitative and qualitative changes in skeletal muscle, with reduction of FFM, muscle strength and physical performance $[1,2]$. This syndrome is also related to the various damages to the health of the elderly, such as frailty, chronic diseases, functional disability and risk factors for the development of Cardiovascular Diseases (CVD), including Insulin Resistance (IR), arterial stiffness and Metabolic Syndrome (MS) [3,4]. Given this, sarcopenia is one of the growing public health concerns in aging populations. 
Obesity, especially visceral obesity, is a fundamental condition of metabolic disorder, considered a chronic disease and directly or indirectly interrelated with other pathological conditions contributing to morbidity and mortality, such as CVD and musculoskeletal and neoplastic disorders $[5,6]$. Therefore, sarcopenia and obesity may synergistically increase their effects on physical disability, metabolic disorders and CVD in the elderly.

The condition of low FFM (sarcopenia) and high FM (obesity) are called Sarcopenic Obesity (SO) which is considered an aging-related syndrome [3]. The prevalence of SO in the elderly varies between $4.4 \%$ and $42.9 \%$ [4]. The etiology of this morbidity includes the complex interactions between the causal factors of sarcopenia and obesity, such as a sedentary lifestyle, an inadequate diet, weight loss, $I R$, decreased growth and testosterone hormones and the production of proinflammatory cytokines by the adipose tissue [4,5-7].

Sarcopenic obesity has been associated to worse physical functioning when compared to isolated obesity and sarcopenia conditions [6], constituting an important cause of frailty and mortality among the elderly [8]. Recently, the association between SO and CVD or Cardiometabolic Diseases (CMD) has received increasing attention $[9,10]$. However, there is no consensus between the definition and classification of SO and this gap contributes to inconsistent findings about its association with clinical outcomes $[4,11]$.

These discrepancies can be explained by the different ways of diagnosing the sarcopenia component, since both Muscle Mass (MM) and muscle strength have been described for this classification. As SO is known to be related to functional impairment, especially the impairment of muscle strength, its evaluation has been recommended as a complementary analysis for the diagnosis of SO [12,13]. In a study by Stephen and Janssen [12], SO was shown to be associated with increased risk of CVD, while obesity and sarcopenia alone were not predictors of CVD. Moreover, this relationship between SO and CVD was found only when SO was diagnosed through muscle strength and not through MM. Thus, the maintenance of muscle strength may be more important than the amount of MM for the prevention of CVD and CMD in old age.

In this sense, the diagnosis of SO may be a better predictor of physical disability and the risk of CVD and CMD than sarcopenia and obesity alone. Moreover, it is suggested to consider for this diagnosis not only MM, but also muscular strength and for this reason it is also proposed in this study to identify, in the articles inserted in this systematic review, the ones that evaluated muscle strength in the elderly with SO.

Studies analyzing the association between SO with risk factors and/or CMD or CVD in the elderly are considered recent [11], which justifies understanding more the issues that evaluate this relationship, such as study design, sample type, instruments used to evaluate body composition and muscle strength in the diagnosis of SO, in order to clarify the impact of SO and its outcomes on the cardiometabolic parameters analyzed. To describe the literature findings on the association between SO, muscle strength and risk factors and/or CMD or CVD in the elderly.

\section{METHODS}

The search for the articles was performed in four databases to be able to capture the published research regarding this thematic in the international literature. For this, the following portals and indexers were used: Medical Literature Analysis and Retrievel System Online (MEDLINE), Web of Science, Latin America and Caribbean Health Sciences Literature (LILACS) and CAPES (Coordenação de Aperfeiçoamento de Pessoal de Nível Superior, Coordination for Higher Education 
Staff Development) Journals. The choosing criteria for the indexers was defined as being available on the internet and with free access. To systematize the information regarding the systematic review process, the START ${ }^{\circledR}$ software (START ${ }^{\circledR}$, v2.03, Campinas, Brazil, 2015) computational tool was used. The purpose of this software was to assist in the Systematic Review process in all its stages: planning, execution and analysis of results [14].

Initially, systems were used to find the controlled terms for the keywords. For the MEDLINE and Web of Science databases, the system used was MeSH (Medical Subject Headings) and for the LILACS and the Capes Journal databases, the system used was DECs (Descritores em Ciências da Saúde).

The search in the indexed databases was performed in English, Spanish and Portuguese with the following search keys: "obesity sarcopenic" OR "sarcopenic obesity" in the title AND "cardiometabolic disease" OR "cardiovascular disease" OR "metabolic syndrome" OR "Insulin resistance" in the title/abstract of the article AND "aged" in all fields of search, with the same procedure for the descriptor "muscle strength". No restrictions on study design were performed. The date of the last search was February 2018.

The selection of articles followed the following inclusion criteria: (a) studies evaluating individuals aged 60 or older; (b) studies published and available in full in scientific databases or in printed versions; (c) studies addressing sarcopenic obesity and CVD/CMD risk, even if they do not refer to muscle strength; (d) studies from 2008 to 2018. And the exclusion criteria were: (a) studies evaluating only sarcopenia and CVD/CMD risk in the elderly; (b) studies that only evaluated obesity and CVD/CMD risk in the elderly; (c) studies that presented evaluations without presenting the method used; (d) animal studies; (e) studies that are not in Portuguese, English or Spanish.

To assess the quality of the study, it was analyzed whether the study was published in peerreviewed journals or event annals, when referring to articles, or approved by the institution's examining board, when referring to undergraduate, masters or doctoral theses. To evaluate the articles, the following criteria were used: the population considered in the evaluation and the statistical methods.

Search strings were built with the keywords and their synonyms. The strings were submitted to the search engines. After reading the abstract and applying the inclusion and exclusion criteria, the study was selected and its relevance confirmed by two reviewers.

The included papers were read in full and the reviewer summarized each one of them, highlighting the methods used for the evaluation and the parameters considered, when necessary. "Data extraction forms" were completed for texts considered valid and which were read in full in the Systematic Review (SR). In addition to the basic information (bibliographic data, date of publication, abstract, among others), these forms have the synthesis of each study. For this activity, the START software was used.

The attributes extracted from the included articles were: authors, year, country, design, population characteristics, diagnostic criteria for sarcopenic obesity, risk factors and/or CMD or CVD, muscle strength assessment methods and main conclusions. The results will be presented descriptively based on the information provided by each of the included studies. For a better presentation and discussion of the articles, they were structured into topics, namely: Sarcopenic obesity: definition and diagnosis; Sarcopenic obesity and risk factors for cardiometabolic and cardiovascular diseases; and Sarcopenic obesity, cardiometabolic and cardiovascular diseases. 


\section{RESULTS AND DISCUSS}

The flowchart of the article selection is shown in Figure 1. The search strategy identified 235 publications in the databases, but 39 of them were duplicates. After reading the 196 titles, 27 records were selected. The 169 exclusions occurred because the articles did not evaluate findings of interest to this study (57), did not exclusively evaluate elderly individuals (32), were not published in English, Portuguese or Spanish (11), were not freely accessible, (27) were not published in the last 10 years (29), did not present their methodology (13). The 27 selected publications were imported into the START software, where the abstracts were read, and the articles were selected for full reading. In this stage, 10 articles were excluded, eight for not evaluating findings of interest to this study, one for not exclusively evaluating elderly individuals and another for not evaluating human beings. There was a total of 17 articles remaining for full reading, of which there was no exclusion. Thus, 17 articles that met the inclusion and exclusion criteria were selected. The studies found on the association between SO and risk factors and/or CMD and CVD are shown in Table 1. Other bibliographic references were cited due to their relevance in the basic theory of this study.
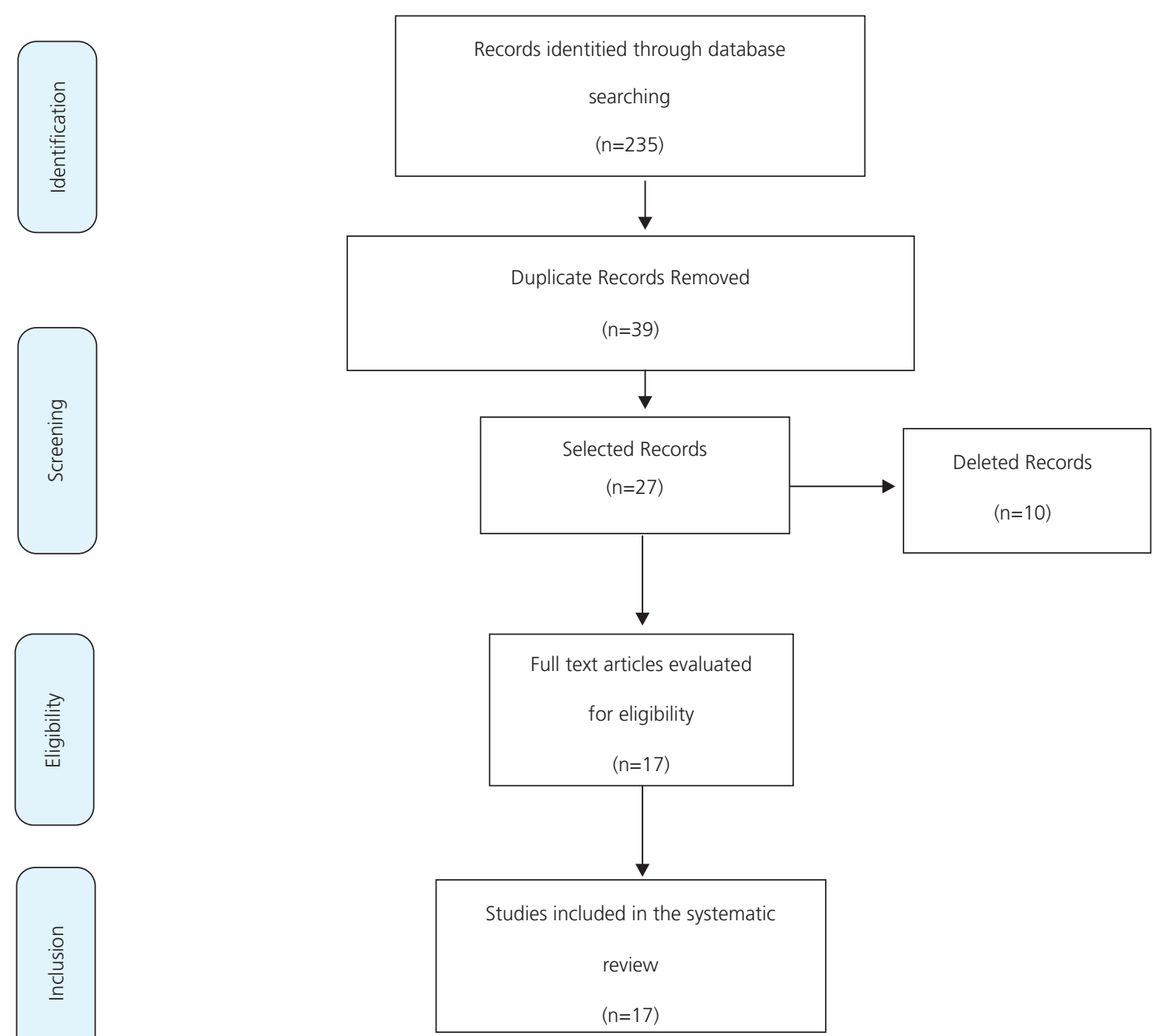

Figure 1. Flowchart of the literature review on the association between sarcopenic obesity and risk factors and/or cardiometabolic disease or cardiovascular disease in the elderly. 
Table 1. Description of studies investigating the association between sarcopenic obesity, muscle strength and risk factors and/or cardiometabolic disease or cardiovascular disease in the elderly.

1 for 3

\begin{tabular}{|c|c|c|c|c|c|}
\hline $\begin{array}{l}\text { Author, year Type } \\
\text { of study and } \\
\text { country }\end{array}$ & $\begin{array}{c}\text { Population } \\
\text { characteristics }\end{array}$ & SO definition & $\begin{array}{l}\text { Cardiometabolic risk/ } \\
\text { cardiovascular disease }\end{array}$ & $\begin{array}{l}\text { Muscle strength } \\
\text { assessment }\end{array}$ & Key Findings \\
\hline $\begin{array}{l}\text { Stephen \& } \\
\text { Janssen, } 2009 \\
{[12]} \\
\text { Prospective } \\
\text { Cohort } \\
\text { USA }\end{array}$ & $\begin{array}{l}n=3.366(M / W) \\
\text { Age } \geq 65 y\end{array}$ & $\begin{array}{l}\text { BIA (AMMEST2); HS } \\
\text { (SC=HS EST-adjust- } \\
\text { ed); Anthropometry } \\
(\mathrm{OB}=\mathrm{WC}) .\end{array}$ & CAD; CHF; CVA. & $\begin{array}{l}\text { Grip strength } \\
\text { dynamometer. } \\
\text { HS adjusted by } \\
\text { the EST. }\end{array}$ & $\begin{array}{l}\text { Coronary event rate in } \\
\text { sarcopenic obese patients } \\
\text { increased } 23 \% \text { (BIA) and } \\
33 \%(\mathrm{HS}) \text {. The risk of CHF } \\
\text { in individuals with SO, } \\
\text { considering the BIA was } \\
42 \% \text { higher. }\end{array}$ \\
\hline $\begin{array}{l}\text { Lim et al., } 2010 \\
\text { [16] } \\
\text { Prospective } \\
\text { Cohort } \\
\text { Korea }\end{array}$ & $\begin{array}{l}n=565(M / W) \\
\text { Age } \geq 65 y .\end{array}$ & $\begin{array}{l}\text { DXA }\left(\mathrm{SC}=\mathrm{AFFMEST}{ }^{2}\right. \\
\text { and AFFM/BM in } \\
\mathrm{kg} 100) ; \mathrm{CT}(\mathrm{OB}=\mathrm{VF} \\
\left.>100 \mathrm{~cm}^{2}\right) .\end{array}$ & MS; HOMA-IR. & NA & $\begin{array}{l}\text { SO (AFFM/EST }{ }^{2} \text { ) was associ- } \\
\text { ated with higher (HOMA-IR) } \\
\text { and higher TGL levels. The } \\
\text { SO group had a risk of } \\
\text { MS } 8.2 \text { times higher than } \\
\text { normal individuals. }\end{array}$ \\
\hline $\begin{array}{l}\text { Kohara et al., } \\
2011 \text { [7] } \\
\text { Cross-sectional } \\
\text { Japan }\end{array}$ & $\begin{array}{l}\mathrm{n}=782(\mathrm{M} / \mathrm{W}) \\
\text { Elderly } \\
\text { individuals. }\end{array}$ & $\begin{array}{l}\mathrm{CT} \quad(\mathrm{SC}=\text { cross-sec- } \\
\text { tional area of the } \\
\text { quadriceps muscle } \\
\text { adjusted by the } \mathrm{BM} \text {; } \\
\left(\mathrm{OB}=\mathrm{VF}>100 \mathrm{~cm}^{2}\right)\end{array}$ & $\begin{array}{l}\text { Leptin; lipid profile; BP; } \\
\text { serum insulin level; } \\
\text { HbA1Cg; HOMA-IR. }\end{array}$ & NA & $\begin{array}{l}\text { Individuals with OS have } \\
\text { higher levels of leptin, fasting } \\
\text { plasma glucose, serum } \\
\text { insulin, HbA1C, HOMA-IR, } \\
\text { and total lym-phocyte count. }\end{array}$ \\
\hline $\begin{array}{l}\text { Hwang et al., } \\
2012 \text { [17] } \\
\text { Cross-sectional } \\
\text { Korea }\end{array}$ & $\begin{array}{l}n=2.221(M / W) \\
\text { Age } \geq 60 y\end{array}$ & $\begin{array}{l}\text { DXA (SC=AFFM/BM } \\
\text { in kgx100); Anthro- } \\
\text { pometry }(O B=W C \\
\geq 90 \mathrm{~cm} \text { for } M \text { and } \\
\geq 85 \mathrm{~cm} \text { for } W) .\end{array}$ & $\begin{array}{l}\text { HbA1C; fasting blood } \\
\text { glucose and insulin; lipid } \\
\text { profile; PTH; vitamin D } \\
\text { levels. }\end{array}$ & NA & $\begin{array}{l}\text { Serum insulin and vitamin } \\
\text { D levels were associated } \\
\text { with SO in both sexes. Serum } \\
\text { glucose and TGL levels have } \\
\text { been associated with SO } \\
\text { in women and PTH levels } \\
\text { increased the risk of SO in } \\
\text { men. }\end{array}$ \\
\hline $\begin{array}{l}\text { Levine \& } \\
\text { Crimmins, } \\
2012[27] \\
\text { Cross-sectional } \\
\text { USA }\end{array}$ & $\begin{array}{l}n=2.287(M / W) \\
\text { Age } \geq 60 y\end{array}$ & $\begin{array}{l}\text { DXA (SC=AFFM/BM } \\
\text { in } \mathrm{kg} \times 100) \text {; Anthro- } \\
\text { pometry }(\mathrm{OB}=\mathrm{WC} \\
>102 \mathrm{~cm} \text { for } \mathrm{M} \text { and } \\
>88 \mathrm{~cm} \text { for } \mathrm{W}) \text {. }\end{array}$ & HOMA-IR; CRP. & NA & $\begin{array}{l}\text { Individuals with SO have } \\
\text { a high level of insulin } \\
\text { resistance. }\end{array}$ \\
\hline $\begin{array}{l}\text { Levine \& } \\
\text { Crimmins, } \\
2012[27] \\
\text { Cross-sectional } \\
\text { USA }\end{array}$ & $\begin{array}{l}n=1.127(M / W) \\
\text { Age } \geq 60 y\end{array}$ & $\begin{array}{l}\text { DXA (SC=skeletal } \\
\text { muscle mass; Anthro- } \\
\text { pometry (OB=WC } \\
>102 \mathrm{~cm} \text { for } \mathrm{M} \text { and } \\
>88 \mathrm{~cm} \text { for } \mathrm{W}) .\end{array}$ & HOMA-IR; CRP. & NA & $\begin{array}{l}\text { The group of individuals } \\
\text { with SO have high levels } \\
\text { of CRP. }\end{array}$ \\
\hline $\begin{array}{l}\text { Chung et al., } \\
2013[23] \\
\text { Cross-sectional } \\
\text { Korea }\end{array}$ & $\begin{array}{l}\mathrm{n}=2.943(\mathrm{M} / \mathrm{W}) \\
\text { Age } \geq 60 \mathrm{y} .\end{array}$ & $\begin{array}{l}\text { DXA (SC=AFFM ad- } \\
\text { justed by the } B M) \text {; } \\
\text { Anthropometry }(O B= \\
\left.\text { BMl> } 25 \mathrm{~kg} / \mathrm{m}^{2}\right) .\end{array}$ & $\begin{array}{l}\text { BP; HOMA-IR; lipid pro- } \\
\text { file; inflammatory mar- } \\
\text { kers; vitamin D levels; liver } \\
\text { function; renal function; } \\
\text { ferritin; leukocytes; MS. }\end{array}$ & NA & $\begin{array}{l}\text { Patients with SO have a } \\
\text { higher vitamin D deficiency } \\
\text { and chance of MS. } \\
\text { HOMA-IR, TGL, ferritin and } \\
\text { leukocytes levels were higher } \\
\text { in the group with SO. }\end{array}$ \\
\hline
\end{tabular}


Table 1. Description of studies investigating the association between sarcopenic obesity, muscle strength and risk factors and/or cardiometabolic disease or cardiovascular disease in the elderly.

\begin{tabular}{|c|c|c|c|c|c|}
\hline $\begin{array}{l}\text { Author, year Type } \\
\text { of study and } \\
\text { country }\end{array}$ & $\begin{array}{c}\text { Population } \\
\text { characteristics }\end{array}$ & SO definition & $\begin{array}{l}\text { Cardiometabolic risk/ } \\
\text { cardiovascular disease }\end{array}$ & $\begin{array}{l}\text { Muscle strength } \\
\text { assessment }\end{array}$ & Key Findings \\
\hline $\begin{array}{l}\text { Lu et al., } \\
2013[24] \\
\text { Cross-sectional } \\
\text { Taiwan }\end{array}$ & $\begin{array}{l}\mathrm{n}=600(\mathrm{M} / \mathrm{W}) \\
\text { Age: } 63.6 \mathrm{y} .\end{array}$ & $\begin{array}{l}\text { BIA }(S C=A M M(k g) / \\
\text { Weight }(\mathrm{kg}) \times 100) \\
\text { Anthropometry } \\
\left(\mathrm{OB}=\mathrm{BMl} \geq 25 \mathrm{~kg} / \mathrm{m}^{2}\right)\end{array}$ & MS & NA & $\begin{array}{l}\text { The group of individuals } \\
\text { with SO showed higher } \\
\text { probability of having MS. }\end{array}$ \\
\hline $\begin{array}{l}\text { Atkins et al., } \\
2014 \text { [8] } \\
\text { Cross-sectional } \\
\text { Great Britain }\end{array}$ & $\begin{array}{l}\mathrm{n}=4.252(\mathrm{H}) \\
\text { Age: } \geq 60 \mathrm{y}\end{array}$ & $\begin{array}{l}\text { Anthropometry } \\
\text { (SC=average arm cir- } \\
\text { cumference; } \mathrm{OB}=\mathrm{WC} \\
>102 \mathrm{~cm}) \text {. }\end{array}$ & $\begin{array}{l}\text { All-cause mortality and } \\
\text { cardiovascular disease- } \\
\text { related mortality; Car- } \\
\text { diovascular events; CAD } \\
\text { Events. }\end{array}$ & NA & $\begin{array}{l}\text { There was no association } \\
\text { between body composition } \\
\text { and other factors evalu- } \\
\text { ated. Individuals with SO } \\
\text { had higher CRP levels. }\end{array}$ \\
\hline $\begin{array}{l}\text { Batsis et al., } \\
2014 \text { [5] } \\
\text { Cross-sectional } \\
\text { USA }\end{array}$ & $\begin{array}{l}n=4652(M / W) \\
\text { Age: } \geq 60 y\end{array}$ & $\begin{array}{l}\mathrm{BIA}\left(\mathrm{SC}=\mathrm{AFFMEST}{ }^{2}\right. \\
\mathrm{OB}=\mathrm{BF} \%)\end{array}$ & $\begin{array}{l}\text { Comorbidities (hyper- } \\
\text { tension, diabetes, CHF, } \\
\text { CAD, smoking and } \\
\text { physical activity). }\end{array}$ & NA & $\begin{array}{l}\text { In the study subjects } 39.0 \% \\
\text { of deaths were from car- } \\
\text { diovascular diseases. No } \\
\text { association was found } \\
\text { between SO and the risk of } \\
\text { mortality in men. Women } \\
\text { with SO had a higher risk } \\
\text { of mortality. }\end{array}$ \\
\hline $\begin{array}{l}\text { Ohara et al., } \\
2014 \text { [29] } \\
\text { Cross-sectional } \\
\text { Japan }\end{array}$ & $\begin{array}{l}n=1.470(M / N) \\
\text { Age: } 64.4 y\end{array}$ & $\begin{array}{l}\mathrm{CT}(\mathrm{SC}=\text { Thigh Cross- } \\
\text { sectional Area; } \mathrm{OB}=\mathrm{VF} \\
\left.>100 \mathrm{~cm}^{2}\right) .\end{array}$ & $\begin{array}{l}\text { Arterial stiffness: pulse } \\
\text { wave velocity of brachial } \\
\text { wrist to ankle arteries. }\end{array}$ & NA & $\begin{array}{l}\text { SO was significantly asso- } \\
\text { ciated with arterial stiffness. }\end{array}$ \\
\hline $\begin{array}{l}\text { Santos et al., } \\
2014 \text { [26] } \\
\text { Cross-sectional } \\
\text { Brazil }\end{array}$ & $\begin{array}{l}n=149(M) \\
\text { Age: } \geq 60 y\end{array}$ & $\begin{array}{l}\text { DXA (SC=AFFMEST2; } \\
\text { OB=FM OS=residual } \\
\text { value of the equation } \\
\text { that provides for the } \\
\text { AFFM based on } \\
\text { height and FM). }\end{array}$ & $\begin{array}{l}\text { BP; lipid profile; HOMA-IR; } \\
\text { CRP. }\end{array}$ & NA & $\begin{array}{l}\text { There was no significant } \\
\text { difference in blood pressure, } \\
\text { blood glucose, HOMA-IR, } \\
\text { lipid profile and inflam- } \\
\text { matory pattern between } \\
\text { the sO group and other } \\
\text { groups. }\end{array}$ \\
\hline $\begin{array}{l}\text { Yang et al., } 2015 \\
\text { [28] } \\
\text { Cross-sectional } \\
\text { USA }\end{array}$ & $\begin{array}{l}n=844(M / W) \\
\text { Age: } \geq 65 y\end{array}$ & $\begin{array}{l}\mathrm{DXA}\left(\mathrm{SC}=\mathrm{AFFMEST}^{2}\right. \\
\mathrm{OB}=\% \mathrm{G})\end{array}$ & $\begin{array}{l}\text { Inflammatory process: } \\
\text { CRP, IL- } 6 \text { and TNF-a. }\end{array}$ & NA & $\begin{array}{l}\text { SO is associated with in- } \\
\text { creased CRP levels in men. }\end{array}$ \\
\hline $\begin{array}{l}\text { Wittmann et al., } \\
2016 \text { [23] } \\
\text { Randomized } \\
\text { controlled trial } \\
\text { Germany }\end{array}$ & $\begin{array}{l}\mathrm{n}=75(\mathrm{~W}) \\
\text { Age: } \geq 70 \mathrm{y}\end{array}$ & $\begin{array}{l}\mathrm{DXA}\left(\mathrm{SC}=\mathrm{MM} / \mathrm{EST}^{2}\right. \\
\mathrm{OB}=\% \mathrm{G})\end{array}$ & MS & NA & $\begin{array}{l}\text { The group of elderly women } \\
\text { with SO showed a higher } \\
\text { chance for having MS com- } \\
\text { pared to the CG. }\end{array}$ \\
\hline $\begin{array}{l}\text { Sanada et al., } \\
2017[22] \\
\text { Prospective } \\
\text { Cohort } \\
\text { Japan }\end{array}$ & $\begin{array}{l}\mathrm{n}=2309(\mathrm{M}) \\
\text { Age: } \geq 71 \mathrm{y}\end{array}$ & $\begin{array}{l}\mathrm{DXA}\left(\mathrm{SC}=\mathrm{AFFM} \mathrm{EST}^{2}\right. \\
\mathrm{OB}=\mathrm{BMI}, \mathrm{BF} \% \text { and } \\
\mathrm{WC})\end{array}$ & $\begin{array}{l}\text { Comorbidities (hyper- } \\
\text { tension and diabetes). }\end{array}$ & NA & $\begin{array}{l}\text { All-cause mortality was in- } \\
\text { creased in men with their } \\
\text { WC-defined SO, but not } \\
\text { their BMI and BF\%. }\end{array}$ \\
\hline
\end{tabular}


Table 1. Description of studies investigating the association between sarcopenic obesity, muscle strength and risk factors and/or cardiometabolic disease or cardiovascular disease in the elderly.

\begin{tabular}{|c|c|c|c|c|c|}
\hline $\begin{array}{l}\text { Author, year Type } \\
\text { of study and } \\
\text { country }\end{array}$ & $\begin{array}{c}\text { Population } \\
\text { characteristics }\end{array}$ & SO definition & $\begin{array}{l}\text { Cardiometabolic risk/ } \\
\text { cardiovascular disease }\end{array}$ & $\begin{array}{l}\text { Muscle strength } \\
\text { assessment }\end{array}$ & Key Findings \\
\hline $\begin{array}{l}\text { Kang et al., } 2017 \\
\text { [9] } \\
\text { Prospective } \\
\text { Cohort } \\
\text { Korea }\end{array}$ & $\begin{array}{l}n=4.183(W) \\
\text { Age: }>61 y .\end{array}$ & $\begin{array}{l}\text { DXA }(S C=A F F M B M \\
\left.O B=B M I \geq 25 K g / \mathrm{m}^{2}\right)\end{array}$ & MS & NA & $\begin{array}{l}\text { Women with SO had a } \\
\text { greater chance of devel- } \\
\text { oping MS. }\end{array}$ \\
\hline $\begin{array}{l}\text { Takayama et al., } \\
2017[10] \\
\text { Cross-sectional } \\
\text { Japan }\end{array}$ & $\begin{array}{l}n=235(M / W) \\
\text { Age: } \geq 65 y .\end{array}$ & $\begin{array}{l}\mathrm{DXA}\left(\mathrm{SC}=\mathrm{MLG} / \mathrm{EST}^{2}\right. \\
\mathrm{OB}=\mathrm{BF} \%) .\end{array}$ & MS & NA & $\begin{array}{l}\text { SO was more associated } \\
\text { with risk for having MS } \\
\text { than just obesity, regardless } \\
\text { of the BMI and other } \\
\text { confounding factors. }\end{array}$ \\
\hline
\end{tabular}

Note: Y.: Years; CVA: Cerebrovascular Accident; BIA: Bioelectrical Impedance; WC: Waist Circumference; CAD: Coronary Artery Disease; DXA Dual Energy X-Ray Absorptiometry; EST: Stature; HS: Handgrip Strength; CG: Control Group; VF: Visceral Fat Abdominal; M: Men; Hba1c: Glycosylated Hemoglobin; HOMA-IR: Homeostasis Model Assessment of Insulin Resistance; CHF: Congestive Heart Failure; IL-6: Interleukin 6; BMI: Body Mass Index; W: Women; BM: Body Mass; FM: Fat Mass; AFFM: Appendicular Fat-Free Mass; MM: Muscle Mass; AMM: Appendicular Muscle Mass; NA: Not Assessed; OB: Obesity; SO: Sarcopenic Obesity; BP: Blood Pressure; CRP: C-Reactive Protein; PTH: Parathyroid Hormone; SC: Sarcopenia; MS: Metabolic Syndrome; CT: Computed Tomography; TGL: Triglycerides; TNF- $\alpha$ : Tumor Necrosis Factor Alpha; BF\%: Body Fat Percentage.

Sarcopenic obesity is not a new subject of scientific research, however, the association between $\mathrm{SO}$ and the risk factors for CMD and CVD in the elderly seems to be more current and has increased the number of studies in the last decade. Seven different countries were identified in the study sample, with the USA ( $n=5)$ having the largest number, followed by Korea $(n=4)$, Japan $(n=4)$, Taiwan ( $n=1)$, Great Britain ( $n=1)$, Brazil $(n=1)$ and Germany $(n=1)$. The cross-sectional clinical design was the most used in the studies $(n=12)$, followed by the prospective cohort $(n=4)$ and only one conducted a randomized clinical trial.

\section{Sarcopenic Obesity: definition and diagnosis}

Sarcopenic obesity is recognized as a condition of simultaneity or coexistence between sarcopenia and obesity $[4,5]$. In addition, it can be considered a "disordered body composition" disorder, which has different associations with age, health and functional capacity, a definition pioneered by Baumgartner [15].

In this study, a variation in the prevalence of SO, ranging between $4.4 \%$ and $42.9 \%$, was also identified. Differences in the prevalence of $\mathrm{SO}$ in the elderly can be explained using different study designs, subject recruitment methods and body composition analysis, as well as the use of various cutoffs for obesity and sarcopenia classification and FFM adjustment by the patient. Body Mass Index (BMI) or height, as well as a wide range of risk factors. Moreover, this variation can also be explained by sex diversity, and some studies analyzed both sexes while others only men or women. In addition, studies were conducted with individuals of different age groups (average age), different sample nationalities, as well as socioeconomic factors and different lifestyles $[16,17]$. All conditions are important for the proper assessment of SO, but studies have highlighted that adjusting the 
amount of MM seems to have a major impact on discrepancies found in the associations between SO and CVD or CMD $[4,12]$.

Different diagnostic methods for SO were identified in the studies included in this review. To assess the total body composition or MM, tests such as Bioelectrical Impedance (BIA), Dual Energy X-Ray Absorptiometry (DXA) and Computed Tomography (CT) were used. Sarcopenia, defined by reduced MM levels, was initially described by Baumgartner [15], based on the analysis of Appendicular Muscle Mass (AMM), measured through DXA, in relation to height. The cutoff point adopted in the study was AMM divided by squared height (AMM/Est ${ }^{2}$ ), two Standard Deviations (SD) below the average of the young reference population. However, this index may underestimate sarcopenia in overweight and obese individuals and overestimate individuals with a low BMI as sarcopenic individuals [18]. In this sense, different cutoff points for sarcopenia diagnosis are described in the literature. A study by Janssen et al. [19] assessed the skeletal mass index (SMI) divided by the individual's Body Mass (BM), both in kilograms and multiplied by 100 ([SMlkg/BMkg]x100), so that individuals were considered to have a Normal SMI if the result of this equation was higher than an above-average specific reference population SD. Newman et al. [18] proposed to classify sarcopenia using two different approaches, as one adjusted the AMM (non-bone and non-fatty tissue of limbs) to the body height (AMM/Est ${ }^{2}$ ), and another used a simple linear regression using the $\mathrm{AMM} / \mathrm{Est}^{2}$ equation, as well as body FM and the $20^{\text {th }}$ percentile were adopted for the specific sex chosen as the cutoff point for each method. The authors suggest that FM should be considered in estimates of sarcopenia prevalence in overweight and obese men and women.

Height-adjusted AMM has been described as the most appropriate index to identify sarcopenia. However, the definition of sarcopenia proposed by study groups such as the European Working Group on Sarcopenia in Older People, the Asian Working Group Sarcopenia, and the Foundation for the National Institutes of Health $[2,20,21]$ suggests not only considering MM, but also deficiency in muscle strength and physical performance.

Interestingly, only one study evaluated muscle strength and Handgrip Strength (HS), the technique used in this study [12]. The findings of this study showed that SO diagnosed from muscle strength, rather than a diagnosis based on MM, was associated with an increased risk of CVD. This information highlights that muscle strength may be more important than $\mathrm{MM}$ in the protection of CVD in the elderly [12]. Further studies incorporating HS assessment, with SO and CVD association, should be promoted. The pathophysiological complexity between HS, SO and CVD in the elderly needs to be better explained.

The multiplicity of cutoff points for identifying obesity was observed in this review. The diagnosis of obesity was made through the analysis of Visceral Fat (VF), BMI, Waist Circumference (WC) and Body Fat Percentage (BF\%). Although CT was used, most studies measured body fat by anthropometry. A longitudinal cross-sectional study by Sanada et al. [22] that investigated the association between the assessment of anthropometric measurements of $\mathrm{SO}$ and all-cause mortality, found that all-cause mortality was increased in men with SO, defined by WC but not BMI and BF\%. This can be explained by the greater sensitivity of WC in identifying the amount of VF, especially in the elderly, because, along the aging process, there is an increase in VF and a reduction in MM [22]. Thus, the use of anthropometric measures, especially WC in the identification of obesity in the elderly seems to be a good evaluation option, besides being an easy to perform, low cost, noninvasive and clinically useful measure. 


\section{Sarcopenic obesity and risk factors for cardiometabolic and cardiovascular diseases}

The association between SO and the risk factors for CMD and CVD is controversial in the studies analyzed. This can be explained by differences in populations and the method used for diagnosing SO. The lipid profile is the most studied risk factor, being present in eleven articles. Of these, eight were performed in Asian elderly individuals $[7,9,10,16,17,22,23,24]$ and only three in non-Asian individuals (the USA, Germany and Brazil) $[12,25,26]$. However, none of the studies analyzed the lipid profile as their main objective, which limits the conclusions about their results. Changes in the lipid profile were characterized by high levels of total cholesterol [24], triglycerides [10,17,23,24] and reduced high-density lipoprotein $[10,17,23-25]$. Studies evaluating the lipid profile of the elderly used the following diagnostic criteria for sarcopenia: the cross-sectional area of the quadriceps muscle adjusted by the Body Mass (BM) through a CT and a height-adjusted MM, and the BM assessed through a DXA and a BIA. For obesity, the measures of VF assessed through a CT and the WC, and the BMI assessed by anthropometry, were used. Most of the studies that presented alterations in the lipid profile were performed in elderly Asian individuals. These usually have a higher BF\% than white individuals of the same age, sex and BMI, representing a higher risk for the development of type II diabetes Mellitus (DM) and CVD [4].

Studies that assessed the inflammatory profile in the elderly showed that individuals with SO had higher C-Reactive Protein (CRP) levels in both sexes [27] or only in men [28]. Also, higher plasma leptin levels were found in sarcopenic elderly men $(p<0.0001)$ and women $(p<0.0001)$, compared to the control group, even after the correction of confounding parameters such as age, weight, height, VF, blood pressure, homeostatic model assessment index and high sensitivity [7]. The study, which examined Interleukin 6 (IL-6) and Tumor Necrosis Factor alpha (TNF-a), showed no difference in the levels of these inflammatory markers among sarcopenic obese elderly adults compared to non-obese sarcopenic individuals [28]. The methods used to diagnose sarcopenia in these studies were the crosssectional area of the muscle through a CT and the MM, height-adjusted by DXA. To identify obesity, the variables employed were $\mathrm{VF}$, FM and $\mathrm{BF} \%[26,28,29]$.

The relationship of inflammatory markers (CRP, IL-6, TNF- $a$ and leptin) and their effects on the condition of low MM and high FM, especially VF in the elderly individual, can be explained by the overproduction of inflammatory cytokines, protein molecules involved. in systemic inflammation and immune responses that are released from adipose tissue cells [6]. Another important effect to note in this process is the negative impact of SO and the inflammation on muscle strength. High levels of IL-6 and CRP have been associated with an increased risk of reduced muscle strength in the elderly [13].

The association of SO with IR has been widely explored in the studies $[6,7,16,17,23,26,27]$. All studies have shown that high levels of IR are found in older people with SO. Visceral obesity, associated with IR, increases the production of proinflammatory cytokines, which act on muscle catabolism, promoting a deterioration in muscle fiber diameter and protein metabolism [6]. Therefore, IR may not only act as a risk factor for cardiometabolic disorders, but also as an additional factor that accelerates age-related decline in MM.

Most studies used the Homeostasis Model Assessment of Insulin Resistance (HOMA-IR) to investigate insulin resistance. In individuals with SO, higher levels of HOMA-IR were found when compared with other groups such as the obese, sarcopenic and control groups $[6,7,16,23,26,27]$. The study by Hwang et al. [17] evaluated fasting serum insulin levels and identified that high levels of this substance increase the risk of SO in both men and women (men: OR $10.1095 \% \mathrm{Cl}$ : 3.41-29.86; women: OR 7.50 (95\% Cl: 3.38-16.64). 
The association between vitamin $D$ deficiency and various noncommunicable diseases, especially CVD and DM, as well as their predisposing factors, such as MS and IR, has been explored in the literature $[17,23]$. Two studies demonstrated the relationship between vitamin D and SO [17,23], all identified that individuals with SO of both sexes have vitamin D deficiency assessed by serum 25 $[\mathrm{OH}] \mathrm{D}$ levels. According to Hwang et al. [17], the $25[\mathrm{OH}] \mathrm{D}$ levels were positively correlated with the amount of lean mass for both sexes and negatively correlated with VF in men. Vitamin D plays an important role in glucose and insulin metabolism. It affects pancreatic islet cells through their receptors and may increase insulin secretion. Vitamin $D$ deficiency leads to increased parathyroid hormone levels and, in turn, reduces insulin sensitivity $[17,23]$. Low vitamin D concentration is suggested to be associated with IR and cardiovascular risk factors [23]. In addition, vitamin D deficiency can influence muscle mass and strength reduction. Therefore, adequate vitamin D levels appear to be an important phenotype for SO prevention in both sexes.

\section{Sarcopenic obesity, cardiometabolic and cardiovascular diseases}

Despite the evidence, the association between SO, CMD and CVD has been less studied. The clinical design of the studies makes it difficult to safely assess this association, as 12 studies used a cross-sectional cohort, while four of them used a prospective cohort and only one was a randomized clinical trial.

Metabolic syndrome has been widely explored in studies [9,10,16,23-25]. These showed that individuals with SO have a higher chance of developing MS in both sexes, when compared with subjects without SO. The diagnosis of SO in these studies was performed using the evaluation of MM, AMM/EST2 indexes, BM by a DXA, skeletal muscle mass by a BIA, obesity by the BMI, WC and $\mathrm{BF} \%$. Takayama et al. [10] showed that regardless of the BMl and other confounding factors such as smoking, alcoholism and level of physical activity, the risk for the development of MS is higher in sarcopenic obese elderly individuals. The relationship with SO can be partially explained by the interaction between high levels of inflammatory markers (CRP, IL-6), BMI and body fat, which are positively associated with a reduction of lean mass $[13,30]$. In this sense, strategies to reduce the impacts of SO on the health of elderly individuals should be studied. Wittmann et al. [25] randomly assessed the effects of electrostimulation on MS in sarcopenic obese elderly women, who were over 70 years old. The results showed that changes in the parameters related to MS were significant $(p=0.001)$ in the group that performed the electrostimulation protocol plus protein consumption (40g/day). Sarcopenic obesity seems to be one of the most adjuvant risk factors for the development of MS in the elderly.

Hypertension has been evaluated in several studies $[5,9,10,22,24-26]$. This, in association with $\mathrm{SO}$, has shown that men and women with SO have higher blood pressure values when compared to individuals who are only obese or sarcopenic, or to the ones considered "normal". The prevalence of this morbidity in the SO population is high. There was a significant difference $(p<0.001)$ in the prevalence of hypertension in the elderly with SO compared with individuals without SO [24]. In postmenopausal women with SO, hypertension was the most prevalent chronic morbidity [9]. Sarcopenic obesity was significantly associated with arterial stiffness and sarcopenic obese individuals tend to consume higher amounts of antihypertensive drugs [29].

In fact, SO is an independent risk factor for hypertension. The precise nature of the relationship between SO and hypertension is not clear. For this reason, further studies that understand 
pathophysiological conditions may be useful for the promotion, prevention and treatment of this disorder in the geriatric clinics [31]. An obvious explanation is the higher prevalence of coexisting risk factors and comorbidities in older adults with SO. Decreased MM associated with elevated WC may predict an increased risk of hypertension, better than an elevated WC alone [31]. Therefore, sarcopenic people have a higher risk of hypertension than normal people with the same WC value.

Some studies also demonstrate an association between SO and DM $[9,24]$. There was a higher prevalence of DM in individuals with SO when compared to other groups $[9,24]$. Diabetes Mellitus is a condition associated with hyperglycemia resulting from the inadequate insulin secretion and/or action required to maintain metabolic homeostasis and has also been shown to impair not only MM but also functionality in the elderly [6].

Studies have identified the presence of CVD installed as Coronary Artery Disease (CAD), Congestive Heart Failure (CHF) and Cerebral Vascular Accident (CVA) in elderly individuals with SO $[5,8,12]$. The presence of SO increased the risk of CVD by $23 \%(p=0.006)$ and the risk of CHF by $42 \%$ $(p=0.002)$ when compared to the normal body composition group [12].

The association between SO and CVD, such as CHF and CAD, seems to be an important predictor of mortality in women. Elderly women with $\mathrm{SO}$ had a higher mortality risk than those without sarcopenia or obesity after adjusting for confounding factors (hypertension, DM, osteoporosis, CHF, CAD, arthritis, non-cutaneous cancer, physical activity, self-reported health status and smoking) (HR 1.29 95\% Cl: 1.03-1.60) [5]. Atkins et al. [8] found that obese sarcopenic men had a higher risk of all-cause mortality but not CVD mortality.

Inconsistencies in the observed associations between SO with CVD risk and mortality risk can be explained by the large variability between studies on sample size, population characteristics and heterogeneity for SO definition and classification. These conditions of variability in the studies are also limiting to assess the association with other variables analyzed in this review, such as risk factors, CVD and CMD.

\section{CONCLUSION}

According to the studies included in this systematic review, it was observed that $\mathrm{SO}$ is a prevalent condition in the elderly, and this may change according to the assessment methods and cutoff points used for classification. Sarcopenic obesity is associated with cardiovascular risk factors, demonstrated by changes in lipid profile, high levels of inflammatory markers, IR and vitamin $D$ deficiency. Only one study evaluated muscle strength, and when it was used for the diagnosis of SO, a greater associated with an increased risk of CVD was observed. There was also evidence of an association between SO and hypertension, DM, MS, CAD, CHF and CVA. The presence of SO increases the chances of CVD by $23 \%$, besides being presented as a predictor of mortality. Some challenges remain to address deficiencies in the knowledge of this syndrome, such as establishing a robust definition of SO to improve study design and thus allowing a better comparison between clinical studies, besides a greater clarity on the main molecular pathways that mediate the connection between both pathologies, thereby enabling the identification of appropriate molecular targets for the development of combined therapies. Addressing these priorities could provide a stronger foundation for more appropriate prevention and treatment options of this common and debilitating condition. 


\section{CONTRIBUTORS}

LS SINÉSIO NETO, participated in the research conception, data collection, writing and reviewing the manuscript, as well as being responsible for the final approval and co-responsible for ensuring the accuracy and integrity of this study. A MEDEIROS, performed the analysis, description of the results, writing and reviewing of the manuscript. A TRAVASSOS and NB OSORIO, participated in the final review of the manuscript. GF NUNES, participated in data collection, analysis and interpretation.

\section{R E F E R E C E S}

1. Ryall JG, Schertzer JD, Lynch GS. Cellular and molecular mechanisms underlying age-related skeletal muscle wasting and weakness. Biogerontology. 2008;9(4):213-28. http://dx.doi.org/10.1007/s10522-00 8-9131-0

2. Cruz-Jentoft AJ. Sarcopenia: European consensus on definition and diagnosis: Report of the European working group on sarcopenia in older people. Age Ageing. 2010;39(4):412-23. http://dx.doi.org/10.1093/ ageing/afq034

3. Cruz-Jentoft AJ, Landi F, Topinková E, Michel JP. Understanding sarcopenia as a geriatric syndrome. Curr Opin Clin Nutr Metab Care. 2010;13(1):1-7. http://dx.doi.org/10.1097/MCO.0b013e328333c1c1

4. Kohara, K. Sarcopenic obesity in aging population: Current status and future directions for research. Endocrine. 2014;45(1):15-25. http://dx.doi.org/10.1007/s12020-013-9992-0

5. Batsis JA, Mackenzie TA, Barre LK, Lopez-Jimenez F, Bartels SJ. Sarcopenia, sarcopenic obesity and mortality in older adults: Results from the National Health and Nutrition Examination Survey III. Eur J Clin Nutr. 2014;68(9):1001-7. http://dx.doi.org/10.1038/ejcn.2014.117

6. Levine ME, Crimmins EM. The impact of insulin resistance and inflammation on the association between sarcopenic obesity and physical functioning. Obesity. 2012;20(10):2101-6. http://dx.doi.org/10.1038/ oby. 2012.20

7. Kohara K, Ochi M, Tabara Y, Nagai T, Igase M, Miki T. Leptin in sarcopenic visceral obesity: Possible link between adipocytes and myocytes. Plos One. 2011;6(9):e24633. http://dx.doi.org/10.1371/journal.pone.0024633

8. Atkins JL, Whincup PH, Morris RW, Lennon LT, Papacosta O, Wannamethee SG. Sarcopenic obesity and risk of cardiovascular disease and mortality: A population-based cohort study of older men. J Am Geriatr Soc. 2014;62(2):253-60. http://dx.doi.org/10.1111/jgs.12652

9. Kang SY, Lim GE, Kim YK, Kim HW, Lee K, Park TJ, et al. Association between sarcopenic obesity and metabolic syndrome in postmenopausal women: A cross-sectional study based on the Korean National Health and Nutritional Examination Surveys from 2008 to 2011. J Bone Metab. 2017;24(1):9-14. http:// dx.doi.org/10.11005/jbm.2017.24.1.9

10. Takayama M, Azuma K, Hayashi K, Shimizu-Hirota R, Makino K, Bessho R, et al. Relationship between sarcopenic obesity and metabolic syndrome among Japanese elderly who underwent a comprehensive health checkup. Health Evaluation and Promotion. 2017;44(4):587-93. http://dx.doi.org/10.7143/jhep.44.587

11. Sena MHG, Silva KC, Medeiros JMB, Daltro CHC. Association between sarcopenic obesity and cardiovascular risk: Where are we? Nutr Hosp. 2016;33(5):1245-56. http://dx.doi.org/10.20960/nh.592

12. Stephen WC, Janssen I. Sarcopenic-obesity and cardiovascular disease risk in the elderly. J Nutr Health Aging. 2009;13(5):460-6. http://dx.doi.org/10.1007/s12603-009-0084-z

13. Schaap LA, Pluijm SM, Deeg DJ, Visser, M. Inflammatory markers and loss of muscle mass (sarcopenia) and strength. Am J Med. 2006;119(6):526-e9-17. http://dx.doi.org/10.1016/j.amjmed.2005.10.049

14. Zamboni A, Di Thommazo A, Hernandes E, Fabbri SCPF. StArt uma ferramenta computacional de apoio à revisão sistemática. Congresso Brasileiro de Software; abr 2010 [citado 15 mar 2019]; Salvador; 2010. Disponível em: https://homes.dcc.ufba.br/ flach/docs/Ferramentas-CBSoft-2010.pdf

15. Baumgartner RN. Body composition in healthy aging. Ann NY Acad Sci. 2000;904(1):437-48. http://dx.doi. org/10.1111/j.1749-6632.2000.tb06498.x 
16. Lim S, Kim JH, Yoon JW, Kang SM, Choi SH, Park YJ, et al. Sarcopenic obesity: Prevalence and association with metabolic syndrome in the Korean Longitudinal Study on Health and Aging (KLoSHA). Diabetes Care. 2010;33(7):1652-4. http://dx.doi.org/10.2337/dc10-0107

17. Hwang B, Lim JY, Lee J, Choi NK, Ahn YO, Park BJ. Prevalence rate and associated factors of sarcopenic obesity in Korean elderly population. J Korean Med Sci. 2012;27(7):748-55. http://dx.doi.org/10.3346/ jkms.2012.27.7.748

18. Newman AB, Kupelian V, Visser M, Simonsick E, Goodpaster B, Nevitt M, et al. Sarcopenia: Alternative definitions and associations with lower extremity function. J Am Geriatr Soc. 2003;51(11):1602-9. http:// dx.doi.org/10.1046/j.1532-5415.2003.51534.x

19. Janssen I, Heymsfield SB, Ross R. Low relative skeletal muscle mass (sarcopenia) in older persons is associated with functional impairment and physical disability. J Am Geriatr Soc. 2002;50(5):889-96. http://dx.doi. org/10.1046/j.1532-5415.2002.50216.x

20. Chen LK, Liu LK, Woo J, Assantachai P, Auyeung TW, Bahyah KS, et al. Sarcopenia in Asia: Consensus report of the Asian Working Group for Sarcopenia. J Am Med Dir Assoc. 2014;15(2):95-101. http://dx.doi. org/10.1016/j.jamda.2013.11.025

21. McLean RR, Shardell MD, Alley DE, Cawthon PM, Fragala MS, Harris TB, et al. Criteria for clinically relevant weakness and low lean mass and their longitudinal association with incident mobility impairment and mortality: The foundation for the National Institutes of Health (FNIH) Sarcopenia Project. J Gerontol A Biol Sci Med Sci. 2014;69(5):576-83. http://dx.doi.org/doi:10.1093/gerona/glu012

22. Sanada K, Chen R, Willcox B, Ohara T, Wen A, Takenaka C, Masaki, K. Association of sarcopenic obesity predicted by anthropometric measurements and 24-y all-cause mortality in elderly men: The Kuakini Honolulu Heart Program. Nutrition. 2018;46:97-102. http://dx.doi.org/10.1016/j.nut.2017.09.003

23. Chung JY, Kang HT, Lee DC, Lee HR, Lee YJ. Body composition and its association with cardiometabolic risk factors in the elderly: A focus on sarcopenic obesity. Arch Gerontol Geriatr. 2013;56(1):270-8. http://dx.doi. org/10.1016/j.archger.2012.09.007

24. Lu CW, Yang KC, Chang HH, Lee LT, Chen CY, Huang KC. Sarcopenic obesity is closely associated with metabolic syndrome. Obes Res Clin Pract. 2013;7(4):e301-e307. http://dx.doi.org/10.1016/j.orcp.2012.02.003

25. Wittmann K, Sieber C, Von Stengel S, Kohl M, Freiberger E, Jakob F, et al. Impact of whole body electromyostimulation on cardiometabolic risk factors in older women with sarcopenic obesity: The randomized controlled FORMOsA-Sarcopenic Obesity Study. Clin Interv Aging. 2016;11:1697-706. http:// dx.doi.org/10.2147/CIA.S116430/

26. Santos EP, Gadelha AB, Safons MP, Nóbrega OT, Oliveira RJ, Lima RM. Sarcopenia and sarcopenic obesity classifications and cardiometabolic risks in older women. Arch Gerontol Geriatr. 2014;59(1):56-61. http:// dx.doi.org/10.1016/j.archger.2014.03.012

27. Levine ME, Crimmins EM. Sarcopenic obesity and cognitive functioning: The mediating roles of insulin resistance and inflammation. Curr Gerontol Geriatr Res. 2012;2012:iD826398. http://dx.doi.org/10.1155/2012/826398

28. Yang CW, Li Cl, Li TC, Liu CS, Lin CH, Lin WY, et al. Association of sarcopenic obesity with higher serum high-sensitivity c-reactive protein levels in Chinese older males: A community-based study (Taichung Community Health Study Elderly, TCHS-E). Plos One. 2015;10(7):e0132908. http://dx.doi.org/10.1371/ journal.pone.0132908

29. Ohara M, Kohara K, Tabara Y, Ochi M, Nagai T, Igase M, et al. Sarcopenic obesity and arterial stiffness, pressure wave reflection and central pulse pressure: The J-SHIPP Study. Int J Cardiol. 2014;174(1):214-7. http://dx.doi.org/10.1016/j.ijcard.2014.03.194

30. Schrager MA, Metter EJ, Simonsick E, Ble A, Bandinelli S, Lauretani F, et al. Sarcopenic obesity and inflammation in The InCHIANTI Study. J Appl Physiol. 2007;102(3):919-25. http://dx.doi.org/10.1152/ japplphysiol.00627.2006

31. Park SH, Park JH, Song PS, Kim DK, Kim KH, Seol SH, et al. Sarcopenic obesity as an independent risk factor of hypertension. J Am Soc Hypertens. 2013;7(6):420-5. http://dx.doi.org/10.1016/j.jash.2013.06.002 